\title{
Kakskümmend kaks kala eesti rahvausundis. III
}

\author{
Mall Hiiemäe
}

räim Clupea harengus membras. Räim on püügikalana märksa olulisem kui temaga samasse heeringlaste sugukonda kuuluv kilu. Eestlase toidulaual on värskel ja silguks soolatud räimel läbi aegade olnud püsikoht (vrd Luts 1998: 121). Piirkonniti on räime nimetatudki silguks (vrd

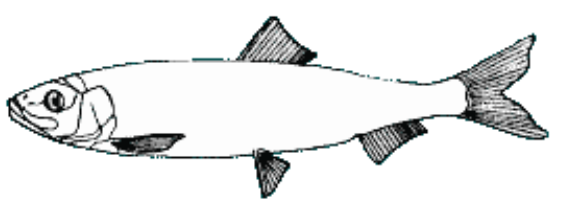
Saareste 1958: 900), sarnaselt räime nimetustega naaberrahvastel (läti k silke, rootsi k sill, soome k silakka, silli, vene k seld). Silk võib märkida veel mistahes soolakala (Võru- ja Setumaal jm), või püügikala mõõtu, suurust, nt väheldase havi kohta öeldakse silk, nolk, pulk, heeringas, pannikala. Samuti võib üldnimetus kala tähendada nimelt räime.

Räim on olnud tööinimese igapäevane toit, suhteliselt odav leivakõrvane aasta läbi nii rannas kui sisemaal, seega vaeste kala, nagu on öeldud Saaremaal: Miks rikkad räimi ei söö? Rikkal on paremat toitu küllalt, mistarvis sööb ta räimest, see on vaeste kala. ERA II 187, 502 (25) < Kaarma khk, Loona v, Hakjala k - E. Ennist (1938). Öeldud on ka vaese mehe heeringas või heeringa poeg. Liigisüstemaatika seisukohalt on need nimetused humoristlikule alatoonile vaatamata üsna tabavad. Nimelt on teadlastel põhjust rääkida läänemere heeringa ehk räime evolutsioonist Läänemerd asustavaks atlandi heeringa alamliigiks. Umbes 5000 aastat tagasi ilmus Läänemere vetesse nii kevadkudu-heeringas kui sügiskudu-heeringas. Meile tuntud kevadräim Clupea harengus membras ja sügisräim Clupea sp. (autumnalis) on nende geneetilised sugulased. Ihtüoloogid on kevad- ja sügisräime pidanud kaheks sesoonseks rassiks, eraldi liikideks või rühmadeks (vt Mikelsaar 1984: 62 jj; Rannak 1988: 9 jj). Loomasüstemaatikaga tegelejatele on teada õige mitmeid erinevusi nende rühmade bioloogias ja nõuetes elutingimuste kohta; eristatakse nn mereräime ja laheräime populatsioone, seost kindlate koelmutega jne (Rannak 1988: 67-74). Suuliselt levivas pärimuses keskendub tähelepanu samuti nendele erinevustele, kuna kõigest sellest oleneb soodsa püügiaja valik. Püügiaja märkimine on motiveerinud u 30\% räime rahvapärastest nimetustest: jääräim, jääkala, jää harv räim, kirskala (kirs on kelts), hallakala, hallaräim, kevademereräim, rohuräim, leheräim, oitseräim, õunapuuõieräim, koerputkeräim, kesaräim, rukkiõieräim, rukkiõitseräim, rukkiloomiseräim, suveräim, suvine räim, mareträim (maretapäeva, 13. juuli aegne räim), lauritsakuderäim (lauritsapäeva, 10. augusti aegne räim), rukkiküliräim, sügismereräim, sügiskuderäim (Mikelsaar 1984: 63 ja 64; Mäger 1973: 13). Rahvapäraste nimetuste rohkuselt ületavad räime vaid ogaliklased - ogalik, raudkiisk ja luukarits, ent nende prügikalaliikide puhul pole ainsagi nimetuse aluseks püügiaeg.

Kevadräime keskmine kudemisaeg on mai keskpaigast juuli keskpaigani, sügisräimel augusti lõpust oktoobri alguseni (Pihu 1987: 88-89). Avamere-räimed alustavad kudemist varem kui laheräimed, kusjuures suuremad kalad tulevad kudema varem (Rannak 1988: 36-38). Selle kohta öeldakse: Kui maamesilane välles, siis on suur räim meres (Vändra). Rahvasuu konstateerib: "Mereulgus" on suured silgud, mis kevade peale jääminekut saab, muul alal neid ei ole (Reigi). O. Loorits (1939b: 53) on nimetuse merehulgus liigitanud eufemismide hulka. Teadetest nimetabu kohta selgub, et räime on nimetatud valge kala, hõbenool (mõlemad Pöide khk). Muidugi ei tohtinud nii tähtsa kalaliigi püügil suhu võtta kardetava metslooma õiget nime. 
Veel aastat 20 ja 30 tagasi oli Pärnu lahes kalapü̈̈djatel, niisama ka räimepüüdjatel pruugiks teravaste järele kuulatada ja järele vaadata, et keegi rannalistest, $k a$ kalapü̈̈djatest ise hunti ega karu ei nimetaks. Karu ja hundi nime nimetamisest kardeti räimepüügile suurt kahju ja sai kohe see inimene, kes karu ehk hunti nimetas, merde kastetud. Selle läbi loodeti tema sõna võimetumaks jäävat. Näitus: Üks Tori kihelkonna mees, kelm ja vallatu, ehk küll elupäevade poolest pääle 50 aastat vana, hüüdnud rannal: "Karu Peeter, kus sa oled?» Silmapilgul asunud kalapüüdjad kallale ja tahtnud merde kasta. Mees rabelenud vastu ja ütelnud, et tema oma sõpra hü̈̈dnud, ja niiviisi jäetud ta veel rahule. H III 5, 582/3 (5) < Tori khk - M. Lindebaum (1888).

Eesti Rahvaluule Arhiivis talletatavates kalastuseteemalistes uskumuste ja kombestiku kirjeldustes on mainitud u 30 kalaliiki. Kolmandikus kõigist neist kalaliiki nimetavatest tekstidest on juttu räimest, seda tänu räime tähtsusele majanduselus. Räim on kalade seas ses suhtes võrreldav mesilasega putukate seas, sarnane on ka uskumuste suunitlus. Siintoodu on väike valik head saaki taotlevat rahvatarkust. (Saagiendeid seoses rahvakalendri tähtpäevadega vt Hiiemäe 1998b: 439-440.)

Räimevõrgu sissepanekul visati võrgukiviga märki. Pihtasaamine võrguvaiale tähendas, et saak tuleb hea (Pärnu).

Kui räimevõrgu vettelaskmisel võrgukivid laksuvad, tuleb hea saak (Häädemeeste).

Esimese räimepüügi aegu ei või keegi võõrast võrgust kala võtta - kaob kogu ranna saagiõnn (Tõstamaa).

Esimesi kevadel püütud räimi tuleb külarahvale jagada, siis on kogu suve hea kalaõnn (Häädemeeste).

Võrku jäänud üksikuid suuri räimi loendati. Paaritu arv tähendas, et saab veel kalu (Reigi).

Püüste või paadi peale pandi kolm räime: kui vares need ära viib, siis on teada, et püügivahendid pole nõiutud - saab veel räimi (Hiiu- ja Pärnumaa).

Kui vankriga randa minnakse ja siga tuleb end vastu vankrit nühkima, saab palju räimi (Viljandi- ja Pärnumaa).

Kui maapinnal on palju väikesi ämblikuvõrke, saab palju räimi (Kaarma, Karksi).

Kui räimedel on silmad punased (ka: nina punane), saab veel palju kala (Hiiumaa, Saare- ja Pärnumaa).

Kui räimede rappimisel rappeid kogemata räimede hulka satub, saab veel räimi (Hiiumaa, Saare- ja Pärnumaa).

Kui räim karjub, siis saab veel räimi (Hiiumaa, Saare- ja Pärnumaa). Kalade puhastamisel ujupõiele surumisest tuleneva heli kohta öeldakse: kala kääksub, kriuksub, kiuksub, kiunub, kiob, karjub kida (vrd kidu - kalarapped; kiduma - rappima).

Paarisarv silku ei tohi süüa, muidu ei saa enam kalu (Vändra, Suure-Jaani).

Vigast räime keelati süüa, kardeti vea ülekandumist sööjale. Rasedal oli oht sünnitada pellagrahaige, kestendava nahaga (kalaveaga) laps: Raskejalgsed inimest äi süü seda, lapsel saab sest viga (Emmaste). Keeld süüa räime silmi ja saba on üldjuhul seotud püügiõnnega, ometi leidub ka teistsugune seletusversioon: Silgu nina ega saba ei sööda mitte, sellepärast et silk meres ninaga surnut nuusutab ja ära minnes lööb ta teda sabaga. E 6057 (15) < Ambla khk, Tapa - J. Ekemann (1893). 
Kalasoomus meenutab härmatiselitreid. Siit lähtub uskumus: Om sügise palju ärma, saab kevadi rohkeste räime (Vändra). Kuna eeldatakse (taas analoogiaprintsiibil) ennejõuluse ja enne-jaanipäevase perioodi ilmade sarnasust, kehtib samasugune mõttekäik kevadräime püügiaja väljaarvestamisel: Mil ajal puud talvel härmas on, siis peab kevade sel ajal randa minema silku (räime) tooma (Juuru). Tähine taevas aastavahetusel võib maapealse elatisehankija kujutluses ette kuulutada rohket noorloomade sündi, teraviljaküllust või kalu täis võrku. Maagilise mõju tagab ajadimensioon: Palju tähti pidi taevas olema, kui võrk üles loodi, siis läheb palju räimi võrku (Emmaste).

Kuna räime sigimisbioloogiat ja üksiti räimeparvede liikumise põhjuslikke seoseid on hästi uuritud, osutub võimalikuks selgitada mõnede pärimuslikus ihtüoloogias levinud loodusvaatluste tõepära. Kalandusspetsialistide andmeil hakkavad räimeparved avamerelt ranniku poole liikuma kohe pärast jäälagunemist, liikudes rannaäärse soojenenud vee suunas, «löövad põhjast lahti», triivivad koelmute läheduses ja siirduvad järk-järgult edasi koelmutele. Saabumine toimub alates $5{ }^{\circ} \mathrm{C}$ ja viimaste kudekala parvede lahkumine $+18{ }^{\circ} \mathrm{C}$ juures (Rannak 1988: 26-33). Siintoodu põhjal võib pidada objektiivseks rahvasuust pärit väidet: Kui kevadised jääd Viru poole tulevad, siis on ka silgusaak Virus (Rakvere). Samasuguseid teateid on Pärnumaalt. Nagu külviaja määramisel, on kalapüügiorientiiriks nn maa õitsemine (mügarikud ja augukesed mullal annavad märku maaelustiku kiirest aktiviseerimisest ja mulla soojenemisest). Ühtaegu soojeneb ka vesi veekogudes ja kudemisränne on intensiivsem. Rahvauskumuse järgi Kui kevadi maa õitseb, siis võib sel aastal randa minna, sest sel aastal oleva hirmus hää räimesaak (Viljandi). Kehtivaks tuleb pidada ka tõdemust: Virvendap päev kevade aia või muu koha pääl, sõs saab mere veeren ästi räimi (Tarvastu). Aiaääre - rannaveere semantilise sarnasuse esiletoomine näib olevat juhuslik, ent toimub nii vee kui maapinnalähedase õhu kiire soojenemine, räimeparved suunduvad ranna lähedale kudema. Mõnes pärimusteates (neid on Viljandi-, Pärnu- ja Tartumaalt) on hea räimesaagi endeks suvine õhu virvendamine. Siin näikse folklooriomane variaablus pärimusteate tarbefunktsiooniga üsna hooletult ümber käivat. On ju suvine õhu virvendamine tegelikult pigem märk sellest, et suvesoojaga kudemine lakkab ja räimeparved seda kiiremini jahedasse meresügavusse siirduvad.

Seda, et räim liigub vastutuult, ilmudes kalda lähedale maatuulega, on märgitud mitmetes teadetes. Öeldud on, et Häädemeestel pole head saaki kagutuulega, Tõstamaal loodetuulega; Emmaste kihelkonna Tilga külas väidetakse, et saaki annab loodetuul, Mustjalas peetakse saagisoodsaks lõunatuult. Vastuolu otsustustes tuule suuna kohta tuleneb siin sellest, et räimeparvede liikumist mõjustavad tuuled eri paigus erinevalt. Räimeparvede rändeteede kaardilt (Rannak 1988: 31) on näha, et pärimusteates nimetatud Tilga külas on loodetuul tõepoolest saagisoodus (loodetuul on siin ka maatuul). Tõstamaalt on kirja pandud rahvatarkus: Räim käib vastutuult enne pööripäeva ja pärituult peale pööripäeva. Siingi on tõetera sees. Kudemisaja lõpupoole, vee soojenedes, lahkuvad räimeparved jahedamatesse ja sügavamatesse vetesse seda kiiremini, mida enam tuul soojenenud veemasse ranna poolt avamerele ajab. Suvine pööripäev täpse ajaorientiiri ja kalade liikumissuuna "pöörajana» on kujund. Vaatlusele ja kogemusele rajaneva pärimusega ongi nõnda, et see on aldis end ilmestama kunstilise kujundi abil, kuid ohustab sealjuures oma tarbeväärtust.

Folkloriseerunud on teave nn kallaspapist - räimeparve liikumissuuna jälgijast, kes põhjaranniku kõrgelt paekaldalt paadisolijaile merel parve asukoha selle kohal lendlevate räimekullide (kajakate) ja vee värvuse järgi kindlaks teeb ning kätte juhatab. O. Loorits (1951: 375384) on selliseid pappe (preestreid) kõrvutanud selgeltnägijate ning arbujatega.

Eelistatud kudemistingimuste kohta kirjutab L. Rannak: «Räim koeb sellistes lahesoppides, kuhu suubub jõevesi - Pärnu lahes muuli otste juures, Matsalu lahe suudmes, Puise ümbruses jm.» Veesisesest taimestikuvööndist Käina lähistel hoiab räim siiski eemale: «Nii otsisime asjatult räime marja ja vastseid Väinamere laidude ümbrusest ja Kassari lahe pool- 
selt alalt, mis on tuntud agariku leiukohana.» (Rannak 1988: 33) Sealtsamast Kassari lahepoolselt alalt pärit üleskirjutuses on samuti juttu räimedest, kes needuse tõttu Käina lahest kadusid. Teine analoogne tekst on Emmastest. Muugalasteks nimetatakse selles tõenäoliselt kalastajaid lõunapoolsetelt randadelt.

Muugalased keind siin enni kala püidmas - Aadu koplis praegu veel nende majade varemed. Nad olla siit ära aetud ja nende võrgud võetud ära. Siis üks muugalaste vanamees pannud kolm räime varda peale ja lasknud vette ja vanne ka veel peale: kus nad kinni võetakse, seal akatakse jälle kalu püidma, siin aga kaduvad kalad ära. Pärnu juures võetud need kalad kinni. ERA II 189, 110 (10) < Emmaste khk ja v, Mänspää k - E. Ennist (1938).

Kalade «kaotamisel» mingist piirkonnast on muistendites märgitud veel räimedele sõlgede külgepanemist, räimede "panemist» kuldsõrmusesse (mõlemad Pühalepa kihelkonnast) või ajamist hõbenõelale (Käina). Traditsiooniliselt on räimede siirdumiskohaks Pärnu laht.

rääbis Coregonus albula on tüüpiline järvekala, kes asustab Peipsit, Võrtsjärve, Saadjärve ja Ülemiste järve. Eesti Rahvaluule Arhiivi teated selle kalaliigi kohta pärinevad Peipsi ja Võrtsjärve ümbrusest. Kirjanduse andmeil koeb rääbis keskeltläbi novembri keskpaigast detsembri kesk-

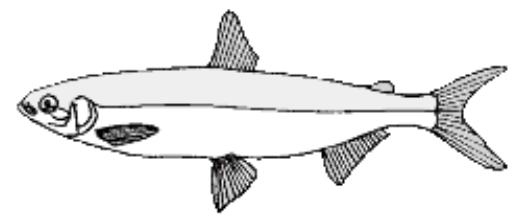
paigani, kudemine vaibub alles jaanuaris (Mikelsaar 1984:

115). Pärimusteate järgi Kodaverest algab kudemisaeg varem - algustähiseks on pakutud mihklipäeva (29. september). Kudemisaja haripunkt on vana mardipäeva aegu (vana kalendriarvestuse järgi 23. november).

Püügihooaeg algab kevadsuvel, konkretiseerituna ajaga enne jaanipäeva, jaanipäeva paiku. Siit tuleneb ka nimetus kesarääbis. Härmatise ja kalasoomuse sarnasusest lähtub uskumus, et kui talvel puudel palju härmatist on, saab suvel palju rääbiseid (Tartu-Maarja). Peipsi põhjarannikul üldtuntud tõekspidamise alusel on põhjatuul hea saagi endeks. Kalateadlase kommentaar annab sellele kinnitust: "Ammust ajast on teada, et Peipsis hoidub rääbis juunija juulikuus (mil ta toitub kõige intensiivsemalt) rohkem tuulepealse kalda lähedale. Nimelt ajab tuul rohkem soojenenud pindmise kihi järve keskosa poole, sügavamalt voolab aga asemele jahedamat vett, mis rääbisele kui külmalembesele kalale on meeltmööda.» (Pihu 1987: 294).

Võrtsjärve mail arvati rääbise suuruse järgi edaspidist ilma ette: Saab järvest rohkest rääbussit ja om nii viil väikse, sõs tuleb kehv aeg ja vihmane suvi (Tarvastu).

rünt - vt lepamaim

silk - vt $\underline{\text { räim }}$

säga Silurus glanis. Eestis üsna väikesearvuliseks jäänud säga on kantud Eesti punasesse raamatusse ning täieliku kaitse all. 20. sajandil teatakse seda magevee

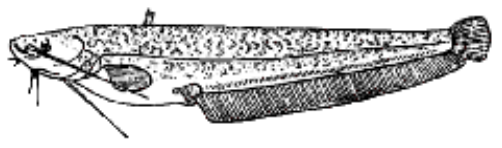
röövkala esinevat peamiselt Emajõe alamjooksul ja Peipsi järves (Mikelsaar 1984: 252-255; Saareste 1958: 900). Rahvapäraseid nimevariante on vähe teada; need on sääkala, sägi, somm (vrd vene k som, läti k sams) jts (Mäger 1973: 14). Säga 
elukohavalikut seletavas rahvajutus ongi tegevuspaigaks Emajõgi. P. Kippari loomajuttude kataloogis (1986: 166) kannab see jutt tüübinumbrit $\mathrm{Mt}^{\circ}$ 256, nimetusega "Kiisk ja säga».

Säga ja kiiss.

Kui säga vanal aal Võrtsjärve on tahtnd elama tulla, siis tulnd talle Emajõe suu pial kiiss vasta. Säga selle kääst küsima: "Kas siin sü̈̈a suab kua?» Kiiss kartnd, et sihuke suur kala nagu säga on, kõik iest ära süöb, ja arvanud parema olema ää laita ning kostnd: "Vuata mind! Kui ma siie tulin, siis oli mul seetse vaksa silme vahe lai, aga vata ku vekseks mind siin nälg on pigistand." Seda kuuldes pöörand säga ümmer ja läind tagasi. H II 49, 845 (4) < Põltsamaa khk - H. Utsal (1894).

F. J. Wiedemanni (1876: 456) seletusversiooni järgi elab säga jõgedes ega söanda merre minna, kartuses jääda väikseks, nagu on kiisk.

Põhiliselt öise eluviisiga mudakalana on loodusharuldus säga vähetuntud, kuid Eesti kalavete asukate seas on säga üsnagi suure kehamassiga esinduslik kalaliik. Seetõttu on tal olnud eeldusi rahvauskumustes omada poolmüütilise hiidkala, «kalade kuninga» mainet. Võib arvata, et siit on saanud tuge ebamäärane kujutlus vee alla tõmbavast näkist, nn tölpsaba orikast või veesügavustes asuvast (haug)sammalseljast (säga selg on rohekas-tumehall, pealagi mustjas-tumehall või rohekashall; Võrtsjärvest, Emajõest ja Peipsist püütud isendite pikkus on olnud u 2 meetrit, keskmine kaal u 40 kg; põhjavees lebavat palginotti meenutab enam säga kui saleda kehaga haug). Kas ei tuleks arvata, et ka Emajões kunagi kohatud roogutil oli tegelikult säga? (Teade on Kolga-Jaanist.)

särg Rutilus rutilus ja roosärg Scardinius erythrophthalmus on liigirikka karpkalaliste seltsi esindajad. Roosärg eelistab rohkem lõunapoolseid vesi, särg on magevete tavalisemaid asukaid kogu Eestis; elada suudavad ka rannikuvetes. Mõlemad annavad lähedaste liikidega (särg latikaga, roosärg nuru ja teistega) hübriide (Mikelsaar 1984: 162-167; 182-186). Rahvapärane süstemaatika peab nende liikide eristamisel särje tunnusteks punaseid silmi ja hõbejat värvust, roosärje tunnusteks kollakaid silmi, kullaläikelist värvust ja punaseid uimi. Vestringi sõnaraamatus on särg Walge Kalla. Liigispetsiifilistele omadustele viitavad rahvasuust kogutud nimetused, nagu valge särg, harilik särg, päris särg, punasilm-särg särje kohta ja kuldsärg, punahänd, punaperse, punatiib roosärje kohta (vrd saksa k Rotfeder - punasulg, ingl k red-eye - punasilm jts).

Õngepüügiks oluline kudemisaeg kajastub nimetustes, mis fikseerivad mingi samaaegse orientiiri fenoloogiliste nähtuste seast. Kuna särg koeb kohe pärast jääminekut, peaksid jääsärg ja keltsasärg olema kasutatud särje kohta või siis välimuselt sarnase teibi Leuciscus 
leuciscus kohta, kes alustab kudemist enne särge. Nimetused lehesärg, lepasärg viitavad vististi optimaalsele püügiajale (vt ka Mäger 1973: 15): Särjekalad olla siis kudemas, kui lepad hiirekõrvul on (pakatama hakkavad), ja olla neid siis kõige parem pü̈̈da (Tori). Jälgitud on kaseurbade pakatamist: Kui kõourb lahki, sis särje kõtt ka lahki (Vastseliina). Ütlus särjed koevad jüripäeva aeg peaks kehtima vana jüripäeva kohta (vkj 6. mai). Veel on silmas peetud rohukonnade krooksumahakkamist (Tartumaa), kanakoolme õitsemist (Halliste), rukkiõitsemise aega (Keila). Võimalik, et viimane märgib roosärje kudemisrännet - selle soojalembese liigi kudemisaeg on hilisem kui särjel, kestes mai teisest poolest juuli alguseni.

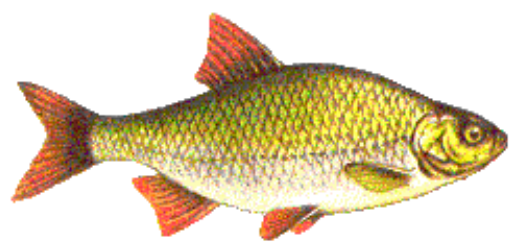

Mitmed nimetused viitavad kala elupaigale või asukohale, liiginimetust täpsustamata: porisärg, mudasärg, muasärg, rabasärg, roosärg, roopuhu, rooservak, rohusärg, jõesärg.

Suhteliselt luise toidukalana pole särjed kuigi kõrgelt hinnatud (särg on sulasekala). Kui kevadel esimesest püügist saadi esimeseks kätte särg, peeti seda halva kalaõnne märgiks (Türi, Tarvastu). Et head saaki pole loota ka talvel, seda järeldati siis, kui viimase sügisese püügi aegu saadi palju särjepuru (Saaremaa). Nagu ahvengi, on särg tavaline ja hästi tuntud, nähtavasti fantaasiat rakendama ärgitava omapärata kala. Ühe napisõnalise jutukese võib arhiivitekstide seast siiski leida (ilmselt on see mõjutust saanud F. R. Faehlmanni müütilisest muistendist «Emajõe sünd» (vrd Fählmann 1840, 41-42).

Säre kalal olevat Emajõe kaevamise aig lehm jalaga pää pääle astnu ja sõrg jäänu pää sisse, sellepärast on särel praegugi veel lehmasõrg pää sisen. H II 29, 399 (94) < TartuMaarja khk, Kavastu v - J.Mägi (1890).

Kas lehmasõra jäljendi all on mõeldud lõpusekaart või luude ja kõhrede kuju, seda pole nii napi teate puhul võimalik täpsustada. Mõne Viljandimaalt pärit teate järgi ei tohtinud süüa särje pead: Kui säre päid sööd, siis tuleb halli tõbi (Tarvastu). Võib-olla tuleneb keeld sellest, et väljapüütud särjekalade hootine võbelemine meenutas malaariahaige (halltõves) inimese vappekülma hoogusid.

tint. Lõheliste seltsi tintlaste sugukonda esindavad Eesti vetes meritint Osmerus eperlanus ja peipsi tint Osmerus eperlanus eperlanus morpha spirinchus (vt Mikelsaar 1984: 134142). Jõgedesse ilmub meritint põhiliselt vaid kudema. Peipsi

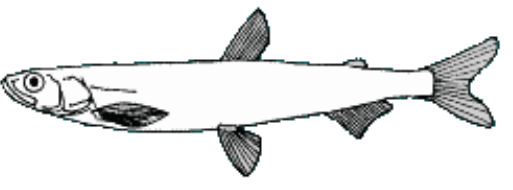
tinti ehk järvetinti peavad ihtüoloogid meritindi mageveeliseks vormiks. Vaatamata sellele, et tegemist on üsnagi väikesemõõduliste kaladega, kuuluvad nii meritint kui peipsi tint oluliste püügikalade hulka.

Kui meritindi spetsiifilist lõhna on kalanduse käsiraamatus delikaatselt värske kurgi lõhnaks nimetatud, siis rahvasuust pärit hinnang selle pisikese pool-läbipaistva kehaga kala kohta on karmim. Tinti nimetatakse haisukott, hobuseliha poiss, hobukala, valge hobuse jalg, tallipoiss, nonnipoiss (Mäger 1971: 25; 1973: 15). Iseloomuliku lõhna päritolu seletab ka rahvajutt. Tindikala saamislooks on rahvasuu kohandanud naljandi aeglase loomuga rannamehest, kes enne paneb piibu põlema ja seejärel asub läbi jää vajunud hobust (või oma naist) päästma. 


\section{Kuidas tindikalad sündin.}

Kihnlane sõitn valge märaga üle mere Pärnuse. Meri oln pagusi [pragusid] täis ja valge kukkn vette. Kihnu Einn mõtlen, et aega küll oo, pann ohjaotsa jala alla, et valge põhja ei vao, ja isi hakkan piibu peale tuld raiuma. Kui piip põlemas, põle va mära enam kõrvagi liigutan. Einn kiskun kelgu kaldale ja jätn valge merepaose, kellest siis pisikesed valge lihaga kalad sigin. Tollepärast olle ka tindidel hoboseliha hais juures. H II 47, 581 (4) < Audru khk - K. Tarkpea (1893).

Rahvajutus esineva kohamäärangu motivatsiooni seisukohalt pakuvad huvi kalateadlaste andmed peipsi tindi esinemisest Võrtsjärves. Nimelt leidus 19. sajandi keskel Võrtsjärves rohkesti tinti, kuid 20. sajandi keskmeks oli see liik sealt täiesti kadunud (Mikelsaar 1984: 141). Rahvapärimus kinnitab kalade kadumist ja annab tüüpilise seletuse. Põhjuseks on tüli, sedapuhku venelastega, teatavasti on kuivatatud tindikala vene-õigeusuliste oluline paastutoit (vrd ka Luts 1998: 122).

\section{Tindikala kadumine Võrtsjärvest.}

Ennemuiste oli Võrtsjärves väga palju kalu, aga kurjad inimesed ajasivad naad kõik ära. Kui ükskord meie rahvas venelastega Puidu all kalu püüdsid, said naad väga palju tindikalu, nii et nende paadid ääreni täis olivad. Aga jagamise juures tuli tüli. Venelane viskas vihaga leivapätsi vette, kalad kõik järele, läksivad ja läksivadki ära ja nü̈̈d ei ole enam ühtki tinti Võrtsjärves leida. E 40716/7 (3) < Tartu I. Kangur (1900).

Virtsjärve (Võrtsjärve) on nimetatud ka Viljandi kihelkonnast pärit jututeisendis; rahvaluulekoguja J. A. Weltmann on kalapüügikohaks nimetanud siin Parika järve.

Uskumuste kirjapanekuid tindist leidub arhiiviteadete seas vähe. Rahvapärimus tavatseb inimesele kõige olulisemate toiduseandjate (mets, vesi, põld, kari) osas saake prognoosida nõnda, et seda tehakse kõrvutavalt. Kui tindisaak oli hea, arvati, et viljasaak tuleb kehv (tuleb nälja-aasta). Teateid on Tartu-, Võru- ja Pärnumaalt, niisiis on mõeldud nii peipsi tinti kui meritinti. Külmtõppe (malaariasse) haigestumist on seosesse viidud tindikala söömisega: Tõbi arvatakse tindikala söömisest tulevat. Sest ta algavat ikka rannaäärsetest küladest, kus kalamehed end peaaegu ainult kaladega toidavad (Karuse). 
tobias - vt tuulekala

tursk Gadus morhua callarias. Tursk (ka: turss) on Eesti rannikuvete kalastiku kogukas esindaja. Sellel lutsuga samasse sugukonda kuuluval röövkalal on iseloomulik välimus: «Pea üsna suur, eest kitsas, suure suuga. Ülalõug ulatub alumisest ettepoole. Hambad lõugadel peened, arvukad. Alalõua all on väike, kuid

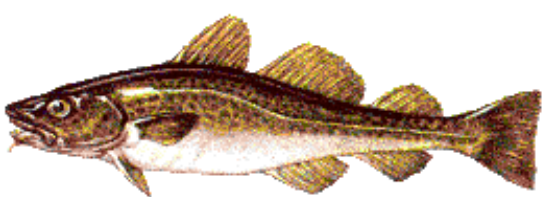
hästi märgatav paaritu poise.» (Mikelsaar 1984: 270). Tursk on võimeline oma suuri lõpuseid ja kurgualuseid kidekilesid hästi laiali ajama (liigikaaslaste ähvarduspoos): Tursal trumm kurkus (Reigi). Suhteliselt pungis silmad asetsevad otsaees lähestikku (tegemist on sügava vee asukaga), alalõualt tolknev jätke meenutab habemetutti. Kõik see annab kalale omapärase koletu ilme. A. Lutsu (1998: 121) hinnangul oli tursa- ja angerjapüük Eestis 19. sajandil juhuslik, kuna rannarahvas neid kalu nende välimuse tõttu põlgas. Rahvasuust pärit kirjelduste järgne koondportree on selline: suur (paistetanud) pea, kõhn keha; tursunud kurgualune, pungis silmad, sarved peas, habe lõua all, alati (või: peale surma) suu lahti. Kõige enam on tursa välimust seosesse viidud vanakuradiga: Tursa pää on sellepärast suur, et ta söönd vanakuradi, mille suur Tõll uputand merre. E 62172 (2) < Tartu - P. Ariste (1928). Sama jututüüp on tuntud liivlastel (Loorits 1926: US 95). Tursakalad on söönd vanapagana rasva ja sellepärast neil silmad pungis ja jalad paistes. RKM II 76, $310<$ Kihelkonna khk, Neeme k - J. Laul (1938).

Paistes jalgu meenutavad tursal eenduva lihasega rinnauimed. Sarvi sellel kalaliigil tegelikult pole.

Süvavee merekalana vajab tursk soolast vett, ent on siiski kohastunud Läänemere soolsuse ja hapnikutingimustega. Kui noorkalade arenguvõimalused on kehvad, võib esineda massiliselt anomaalseid, nagu kokkusurutud selgrooga «juppturski» (Mikelsaar 1984: 274-275). Kurtunud väljanägemise ja lahja (väherasvase) liha tõttu on Saaremaal turska nimetatud kerenskiks (vihje väikese maksujõuga tsaariaegsele rahaühikule) ja maunuseks.

Saaremaal nimetati turska maunuseks. See nimi on tulnud ühest kalurist, kes olnud tiisikushaige. Selle mehe nimi olnud Maunus ja ta olnud kehast õige kõhn, ainult pea olnud suur nagu tursal. E 84478 (6) < Saaremaa - J. Rebane (1933).

Nimetus villamaa mees (Reigi) tulenevat sellest, et Villamaa külas olnud mitmel elanikul perekonnanimeks Tursk. Fenoloogiliste nähtuste samaaegsusele osutavaid nimetusi tursa kohta ei ole teada. Tundub, et siin on nimeandmisel lähtutud ennekõike vajadusest olulise püügikala kohta kasutada peitenime. Märkimist on leidnud seos merega. Tursk on mere ulgus, suure mere põrsas (Saaremaa nimetused), seda ka regivärsilises kalastajaloitsus (läänesaartelt on neid üsna mitmeid variante):

Kui turski pü̈̈dma haketakse, siis saab kolm korda tursaõnge peale sülitud, mütsiga ühest kohast teise uhjutud, kolm korda nuusutud ja siis lausutud:

Tule, tule tursuke, merepöhja pörsuke, hakka otsa, halli poissi, liiguta mu linast paela, katsu mu koogu kõverat rauda.

Siis saab esimise tursa suhe kolm kord sülitud, siis tulla tursad igalt poolt kokku. E 30061/2 (42) < Jämaja - A. Kuldsaar (1897). 
Mainitud pael, kook ja kõver raud on õnge osad - vanasti püüti turska põhjaõngedega. Õngegi ei tohtinud õige nimega nimetada, seda öeldi nt türsiks (Emmaste), õngitsemist aga juksamiseks (Kuusalu). Selle kohta, millal, millest ja kuidas tursaõnge valmistada, on mitmeid õpetusi. Õnge ei soovitatud teha lihtsalt metallist, vaid see tuli valmistada nt vanast väravahaagist, et siis hakkab paremini külge, või hõbehelmest, surnuristi naelast või koguni surnuluust (kõik teated on Saaremaalt).

Kui tahetud head tursaĩnne saada, siis pandud tursakolgid ikka surnuluudest. Toodud päris Kihelkonna surnuaialt tursakolkide jaoks surnuluid. Muidu on need kolgid ikka tinast. ERA II 255, 454/5 (15a) < Kihelkonna khk ja v, Undva k - J. Laul (1939).

Tursaõngi on soovitatud ka surnuaialt toodud mullaga suitsutada, kusjuures see pidi olema võetud värskelt haualt (Mustjala). Valjalast on pärit kirjapanek: Kui kõva tursasaak oli, [öeldi] et jälle tuleb mailmasõda, nagu oleksid siin tursad seosesse viidavad hävinguga inimeste seas.

Seos surnu või surmaga ei tundu tursa puhul olevat lausa juhuslik. Hiiu- ja Pärnumaalt on teateid, et võrgust leitud tursakala visati tagasi vette. Arvati, et selle söömine toob haigust või isegi surma. Võib-olla polnud soovitav «merepõhja põrsukese» sattumine just võrkudesse? Usundiliste muistendite lähemal vaatlusel selgub, et tursal on, nagu haugilgi, oma koht mütoloogilise allvee-ilma olendite seas. Vetevalla ühesilmaga orika püüdmine võis kätkeda endas ohtu. Tegemist on rahvusvaheliselt tuntud muistendiga, milles veealused vaimud oma sigade (täpsemalt: emise, orika, põrsa) eest hoolt kannavad (vrd HDA VI: 1406, 1411).

Hiidlased olid Tahkurannas kalapüügil. Ühel päeval kukkus üks kalameestest merde. Küll otsiti ja otsiti, kuid leida polnud teda kuskilt. Viimaks tuli mees ise vee seest välja ja ronis laeva. Vahepääl oli teine kalamees veest välja tõmbanud ühe ühesilmaga tursa. Niipea kui veest välja roninud kalamees ühesilmaga tursa laevas nägi, haaras selle kätte ja viskas merde tagasi, üteldes: "Säh oma ühesilmaga orikas!» Teised kalamehed hakkasid imestades küsima, miks ta kala merde tagasi viskab. Nü̈̈d jutustas mees, mis ta meres näinud. Ta kukkunud mere põhja ilusa õue pääle. Õues olnud üks vanamees, see tulnud ja hakanud temaga riidlema seepärast, et kalamehed iga päev omad võrgud ta karjamaa väravasse laskvat, veel täna olevat nad viinud talt ühesilmaga orika, ja lubanud kalamehi karistama hakata, kui need teda ükskord rahule ei jäta. ERA II 9, 233/4 (14) < Ridala khk, Sinalepa v, Tuuru k - M. Meiusi (1928).

Tursa kui mütoloogilise olendi tunnuseks võib olla ka see, et kalal on üksainus (veri)punane silm (Kihelkonna). Ühes Hiiumaa muistendis satub kalamees kalavaimuga konflikti seetõttu, et on püüdnud koguni hulga ühesilmalisi kalu (Russwurm 1861: 94). Ühe või kolme silmaga vm eritunnustega kala on Ivar Paulson pidanud nii eesti kui naabermaade usundis kalastajakultuurile tunnusliku kaitsevaimu-haldja kehastuseks (Paulson 1997: 71 jj). Tursa välimuse seosesseviimine kuradiga (vanakuradi liha söömine, kuradi atribuut - sarved) kuulub juba hilisemasse, maaviljeluskultuuri aegadesse. Mis puutub ühe silmaga tursakaladesse, siis kohatud on isegi pimedaid kalu. «Kui kala mingil põhjusel kaotab nägemise, muutub ta harilikult süsimustaks, sest «näeb» ainult pimedust. Niisugust nähtust täheldatakse aeg-ajalt turskade hulgas,» väidab E. Pihu (1987: 314).

Hiljaaegu (1995. a) laekus folklooriarhiivi ebatavaline uskumusteade linnupette kohta: Vahest, et kala, et kui ommiku leiba pole söönd, et tühja kerega lähed - kala pettis äe. Turss pettis (Valjala). Kala pole ju lind, kelle hääle kuulmine võib söömata välja läinud inimese «ära petta». Näib, et tegemist on juhusliku ülekandega, pelgalt kujundiga. Tahaks siiski uskuda, et mitte. Põhimõtteliselt on tursk eesti rahvausundis niisamasugune teispoolse ilma esindaja nagu kevadised linnudki (vrd Hiiemäe 1996: I, 10-13). 
tuulekala. Eesti rahvapärases ihtüonüümikas võivad tuulekala nimetust kanda õige mitmed kalaliigid. Need on vä-

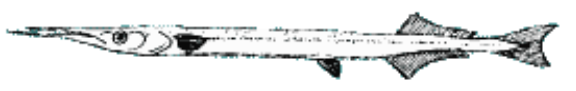
liselt mõnevõrra sarnased, iseloomuliku peene, nõelja (madu, nõela või nöörijuppi meenutava) kehakujuga kalad, tuulehaugiliste seltsi kuuluv tuulehaug Belone belone, ogalikuliste seltsi esindajad merinõel Syngnathus typhle, madunõel Nerophis ophidion ja ka neist veidike tüsedamad raudkiisk Spinachia spinachia ning ahvenaliste seltsist väiketobias ehk nigli Ammodytes tobianus ja suurtobias Hyperoplus lanceolatus (vt Mikelsaar 1984: 256-259; 288-295; 335-343). Seos tuulega ilmneb suures osas nende kalaliikide rahvapärastest nimetustest: tuulekala, tuulehavi, tuulenõel, tuuleling, tuulenool, tuuleuss, tuuleving, tuulevink, tuuleviu, tuuleviuk, tuulingas, tuulenäitaja jts (Mäger 1973: 4546; Mikelsaar 1984: 426). Soomes nimetatakse suureks ja väikeseks tuulekalaks (isotuulenkala, pikkutuulenkala) tobiaid (niglisid); analoogne on seletus Häädemeestelt: Nigli on pikk ja oige peenike, orataoline kala, vist sama, mida ka tuulenõela nime all tuntakse. Rahvapärased nimetused ei tarvitse olla liigispetsiifilised - ühte ja sama nime kasutatakse piirkonniti eri kalaliigi kohta või siis ei eristata neid liike üksteisest. Näiteks usja kehaga silmusid on teinekord samuti tuulekalaks nimetatud.

Tuulekala koondportree annab kirjeldus põhjarannikult: Vahel leiavad kalamehed räimi pü̈̈des räimeste hulgast kala, mis on niidi jämedune, umbes jala pikkune, ussi sarnane, imeväikese peaga. Kalamehed nimetavad seda olevust tuulenõelaks. ERA II 199, 187 (13) < Haljala khk, Vihula v - A. Rootalu (1938).

Tuulekalu kasutatakse nagu kuivatatud merehärgagi, tuule suuna teadasaamiseks: Nie tuuleviugud näütäväd kohe, ku kuo tuod, kust puold tuul on, neh kierdäväd nenä tuule puole rippujes (Kuusalu). Raudkiisa kasutamise kohta leidub märge Mikelsaare raamatus (1984: 290): «Majanduslikku tähtsust ei ole. "Külmatõve kalana» on rahva jutu järgi soovitatud külmetumise korral tema tuhka sisse võtta, «tuulenäitajaks» aga nööriga lakke riputada(!).» Kuivatatud tuulekala ülesriputamine tuulelipuks on meremeeste ja rannaperede tava; samuti on toimitud nn ilmakalaga (saksa k Wetterfisch) nt Taanis (HDA IX: 520). Kalade seosesseviimisele tuulesuuna näitamisega on nähtavasti põhjust andnud lõunapoolsete merede asukate (kuuluvad samasse tuulehaugiliste seltsi) - pääsukalaliste sugukonna esindajate kohastumuslikud iseärasused - võime mõnda aega õhus püsides «lennata» (vt Loomade elu 4: 1979: 264266). Hüppeid veest välja teevad ka parves liikuvad tuulehaugid, otsekui suunda näidates. Madu- ja merinõela puhul tuleks vististi suunanäitamiseks pidada nende püstist ujumisviisi ja omadust saba abil vetikate külge kinnitudes end kestvalt püstasendis veehoovusest kaasa tõmmata lasta (vrd Mikelsaar 1984: 293). Tõenäoliselt nimetatakse neid tuulekaladeks siiski vaid noolja kehakuju, mitte käitumuslike iseärasuste pärast.

Rohekate luude ja pika nokataolise ninamikuga tuulehaug (ka: nokahaug) on püügikala, kes ilmub meie rannavetesse enne jaanipäeva. Rannakalurid otsustavad selle järgi, kauaks räimepüüki on: kui tuulekala esinema hakkab, on pool räimet veel ees (Püha); kui tuulekala püütaks, siis üteldaks sedamoodi, et see kevade on silgupü̈̈k läbi (Käina).

tuur Acipenser sturio kuulub põhjapoolkera vesi asustava tuurlaste sugukonna eriti hinnatud vääriskalade hulka. Kevadise suurvee ajal ilmub tuur merest jõge-

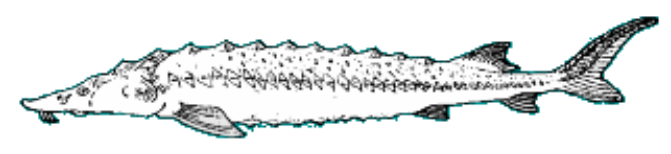
desse; kudemisaega arvatakse olevat juunis (Mikelsaar 1984: 56-60). See kalaliik äratab tähelepanu oma kogukusega: Põhjamere vetest püütud tuura pikkuserekord on $350 \mathrm{~cm}$, kaal $320 \mathrm{~kg}$. Narva jõest 1945. a püütud tuur oli pikkuselt peaaegu võrdne 1996. a Väinamerest püütud isendiga (vastavalt $288 \mathrm{~cm}$ ja $290 \mathrm{~cm}$ ), ent Väinamerest püütud haruldus - Mariaks nimetatud emaskala - oli raskem (vastavalt $128 \mathrm{~kg}$ ja $135 \mathrm{~kg}$ ). 
Eesti punasesse raamatusse kantud tuur oli kunagi arvestatav püügikala nii marja kui liha poolest (vrd Luts 1998: 122). Kahe tuura stiliseeritud kujutis leidub keskaegsel Narva vapil. Ühe seljauime asemel on vapikaladel kaks ja pärakuuim puudub, rõhutatud on tuura massiivsust. Sama kujutist on kasutatud rootsiaegsetel Narvas vermitud 17. sajandi ööridel (vt Haljak 1993: 113-116).

Nimetus tuurakala (Kihnus tüürakala) on Läänemere kalastajarahvastega ühist algupära (vrd rootsi k stör, inglise k sturgeon, saksa k Stör, läti k store ja ladina k nimeosis sturio). Tähelepanu väärib siinkohal põhjaranniku nimetus samb, millele soomlastel vastab tuura kirjakeelne liiginimi sampi. Saareste sõnaraamatus (1958: 899) leidub näitelause Kuusalust: «Meie rannas oli vanast ka sambisid nähtud.» Soome ja karjala usundis ei tähenda sampokala pelgalt liiginime, vaid üksiti müütilist hiidkala, keda võib esindada samuti veel mingi muu kalaliik, nt haug, tursk või säga (Mäkeläinen 1976: 328-332). M. Kuusi arvates võib klisheelisi jälgi Volga alade kosmoloogilise soome-ugri maailmamüüdi ürgmere kolmest maakandjast leida ka soome, karjala ja eesti regilauludes. Need kolm hiidkala on suurte jõgede tuurlased beluuga Huso huso (Kuusil Acipenser huso), sevrjuuga Acipenser stellatus ja vene tuur Acipenser gueldenstaedti. Kuusi arutlusest selgub, et regilaulu mugandunud väljend tuonen otra on suguluses vene keeles tuurlaste kohta kasutatava kalanimetusega osetr ja kosmoloogilist sampo-kala kehastab läänemeresoome piirkonnas ikkagi haug (Kuusi 1976: 316-322).

Eesti rahvapärimuses ei ole tuura kohta teada mingisuguseidki andmeid, temast kui müütilisest hiidkalast rääkimata. Võib siiski arvata, et korpulentse tuura taandumisega Läänemere vetest jäi liik unustusse ka rahvapärimuses, ent pigem dimensioonidest kui liigist lähtunud hiidkala-kujutelm elas koos teiste kalaliikidega edasi. Seoses sampo-kala problemaatikaga vääriks lähemat jälgimist teisegi õige massiivse kehaga kalaliigi, säga venekeelse nimetuse som (vrd läti k sams) etümoloogiline taust.

vingerjas Misgurnus fossilis; Cobitis fossilis kuulub hinklaste sugukonda. Selle peidulise ja öise eluviisiga mudakala (vrd soome mutakala) teadaolevad asualad paiknevad Kagu-Eestis. Rahvapäraseid nimetusi on palju, kuid kõigi puhul pole selge, kas need märgivad vingerjaid või teisi lähedasi liike. Kuna tegemist on häälitseva kalaga (vingumist või kriuksumist meenu-

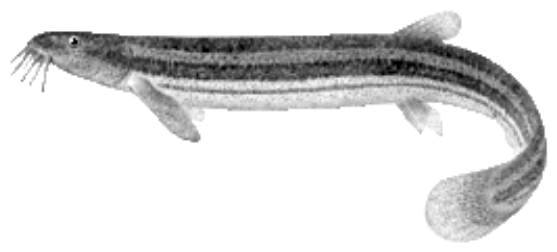
tav hääl tekib gaaside väljutamisel kala soolestikust), on see aluseks nimetustele, nagu kidiseja, vigiseja, vigijas, kräuks jts (vrd Mikelsaar 1984: 249-251). Silinderja keha ja väikese peaga vingerjas meenutab madu, seepärast on teda nimetatud ussikalaks ja siukalaks. Setu ja võru murdes tuntakse nimetusi jonn, jont, junn, mis on nähtavasti vaste venekeelsele liiginimetusele vjun. Mujal võib junn kalanimena kasutatud olla näiteks lutsu või emakala kohta (vrd Saareste 1958: 889).

Keeleteadlane Julius Mägiste on Setumaalt kirja pannud ühe huvitava legendi jonniks nimetatavast kalast. Võib arvata, et kõnesolev jooniline kalakane on vingerjas, kelle üks liigiomaseid tunnuseid on kolm tumedat külgmist pikivööti.

Jonn, kalakane, sääne jooniline. Vanahalv rotile and tuu kura nõu sisse. Tegi rott mulgu laivale sisse ja tahtse laiv sisse minna' ja jonn tsusas hanna ette, tuu rotimulgu ette. Sis ütel jummal: "Sina saat kõke edimäne kala olema." Jonne ei ole patt süvvä', ta om jäle küll kaia. (Olevat «kiräh»). KKI, WS < Setu, Varesmäe - J. Mägiste (1934).

Tegemist on A. Aarne tekke- ja seletusmuistendite kataloogis leiduva rahvajututüübi Aa US 61 paralleeliga. Aa US 61 on tuntud ka Setus, keskseks tegelaseks on madu, kes torkab oma saba augu ette Noa laevas, mistõttu vesi ei pääse sinna sisse voolama. 
J. Mägiste märkus, et talle jutustatu olevat «kiräh», tähendab siin ehk jutustaja vihjet veeuputuslegendi piibli-päritolule ega puutu siintoodud tekstivariandi nüanssidesse. Igatahse pole selles midagi loogikavastast, et mao asemel saab sedapuhku vingerjas tänu oma heateole priviligeeritud staatuse. On ju jonni ehk vingerjat nagu angerjatki sarnasuse tõttu maoga peetud mao teisikuks. Niisuguse uskumuse olemasolule annab kinnitust Torma päritoluga arhiivitekst Kui (Peipsi?) järves enne jüripäeva mürinat on kuulda, siis lähevad vingerjad ussiks.

vinträim- vt kuldkala

võldas - vt merihärg 